\title{
BMJ Open Prevalence and risk factors for SARS- CoV-2 infection in children with and without symptoms seeking care in Managua, Nicaragua: results of a cross- sectional survey
}

\author{
Jorge A Huete-Pérez (D) , ${ }^{1}$ Kacey C Ernst, ${ }^{2}$ Cristiana Cabezas-Robelo, ${ }^{1}$ \\ Lucia Páiz-Medina, ${ }^{1}$ Sheyla Silva, ${ }^{3}$ Alejandra Huete ${ }^{4}$
}

To cite: Huete-Pérez JA, Ernst KC, Cabezas-Robelo C, et al. Prevalence and risk factors for SARS-CoV-2 infection in children with and without symptoms seeking care in Managua, Nicaragua: results of a crosssectional survey. BMJ Open 2021;11:e051836. doi:10.1136/ bmjopen-2021-051836

- Prepublication history and additional supplemental material for this paper are available online. To view these files, please visit the journal online (http://dx.doi.org/10.1136/ bmjopen-2021-051836).

Received 30 March 2021 Accepted 13 September 2021

Check for updates

(C) Author(s) (or their employer(s)) 2021. Re-use permitted under CC BY-NC. No commercial re-use. See rights and permissions. Published by BMJ.

${ }^{1}$ Molecular Biology Center, Universidad Centroamericana, Managua, Nicaragua

${ }^{2}$ Department of Epidemiology and Biostatistics, The University of Arizona Mel and Enid Zuckerman College of Public Health, Tucson, Arizona, USA

${ }^{3}$ Pediatrics Unit, Vivian Pellas Hospital, Managua, Nicaragua ${ }^{4}$ Mount Auburn Hospital, Cambridge, Massachusetts, USA

Correspondence to Dr Jorge A Huete-Pérez; jorgehuete@uca.edu.ni

\section{ABSTRACT}

Objective This study aimed to capture key epidemiological data on SARS-CoV-2 infection in Nicaraguan children ( $\leq 18$ years) seeking medical care, between 6 October and 16 November 2020.

Design In this cross-sectional study, 418 children were recruited: 319 with symptoms characteristic of COVID-19 and 99 with no symptoms of illness. Children were tested for SARS-CoV-2 RNA using loop-mediated isothermal amplification. A questionnaire was employed to identify symptoms, risk factors, comorbidities and COVID-19 prevention measures.

Setting Research was carried out in four hospitals and two clinics in Managua, Nicaragua, where schools and businesses remained open throughout the COVID-19 pandemic.

Participants Children were enrolled into a possible COVID-19 group if presenting with clinical symptoms. A comparison group included children lacking any COVID-19 symptoms attending routine check-ups or seeking care for issues unrelated to COVID-19.

Results A high prevalence (43\%) of SARS-CoV-2 infection was found, which was relatively equivalent in symptomatic and non-symptomatic children. Age distribution was similar between symptomatic and non-symptomatic children testing positive for SARS-CoV-2. Symptomatic children who tested positive for SARS-CoV-2 were 2.7 times more likely to have diarrhoea ( $26.7 \%$ in positive vs $12.0 \%$ in negative; $\mathrm{OR}=2.7$ (95\% $\mathrm{Cl} 1.5$ to 4.8$), \mathrm{p}=0.001)$ and were 2.0 times more likely to have myalgia (17.8\% in positive vs $9.8 \%$ in negative; $\mathrm{OR}=2.0(95 \% \mathrm{Cl} 1.0$ to 3.8$)$, $\mathrm{p}=0.04)$. Children with COVID-19 symptoms, who tested positive for SARS-CoV-2, were more likely to be under age 5 years and to have a pre-existing comorbid condition than children who tested positive but did not have symptoms. Conclusions This is the first paediatric study to provide laboratory-confirmed data on SARS-CoV-2 infection in Nicaragua, crucial for paediatric health services planning and a successful COVID-19 response. The high prevalence of the virus suggests widespread and sustained community transmission, underscoring the urgent need for robust data on the true extent of SARS-CoV-2 infection throughout Nicaragua.
Strengths and limitations of this study

- Primary data from low-income countries are urgently needed. This is the first study providing data obtained from testing of SARS-CoV-2 infection in the Nicaraguan paediatric population, presenting evidence that fills a major research gap.

- We accomplished this by using a simple, highly sensitive detection technique, loop-mediated isothermal amplification, which may be used in developing countries both as a detection method and for epidemiological surveillance.

- Our study indicates widespread and sustained community transmission in Nicaragua, particularly among children, an issue that merits additional urgent attention to improve the overall response to COVID-19 disease.

- This research is critical, considering the lack of effective pandemic response and of credible COVID-19 statistics in Nicaragua.

- The study's data may not reflect the national prevalence of SARS-CoV-2 among Nicaraguan children since most children were from the capital of Nicaragua, and it is possible that some individuals were more likely to participate if they had a history of close contact with confirmed cases.

\section{INTRODUCTION}

The Latin American and Caribbean regions continue to face serious difficulties in containing the COVID-19 pandemic, with more than 21.8 million confirmed COVID-19 cases and 689 967 deaths. ${ }^{1}$ The situation may be more difficult in the countries of Central America, such as Nicaragua, where insufficient health services and limited infrastructure are the norm. The Nicaraguan Ministry of Health confirmed the first COVID-19 case in Nicaragua on 18 March 2020. However, more than a year later, not much is known about the true COVID-19 situation in Nicaragua, and it is almost impossible to assess 
the growth of the pandemic, as testing is largely unavailable. Official data lack accuracy and transparency, resulting in little public confidence. As of 24 February 2021, the official government count admits to only 6445 confirmed cases and 173 deaths, ${ }^{2}$ but the Citizens Observatory of COVID-19, an independent research group, estimated a cumulative number of cases of 13140 and with at least 2976 deaths from COVID-19, making it one of the highest COVID-19 mortality rates in Latin America. ${ }^{3}$ Furthermore, official death tolls undercount the total number of fatalities and the government-run health centres seldom report COVID-19 as the cause. Between March and August of 2020, the number of deaths exceeded the average number of deaths in previous years by 7600 , a figure that was $47 \%$ higher than the expected number for that period and almost 50 times the deaths officially attributed solely to COVID-19. ${ }^{4}$

In direct contrast to most Latin American countries, the Nicaraguan authorities refused to implement any significant public health or social interventions in response to the pandemic. ${ }^{5}$ While more than a hundred countries had closed in-person school attendance by mid-March, $2020,{ }^{6}$ the Nicaraguan government kept public schools open all through the pandemic, and there were no restrictions imposed on transport and mobility. However, school attendance was irregular, varying by grade and geographical area, and some parents decided not to send their children to school. These closures and irregularities confound the understanding of children susceptibility to SARS-CoV-2 infection.

Clinical manifestations of COVID-19 are generally milder in children compared with adults, ${ }^{7}$ although some children do require hospitalisation and intensive care. ${ }^{8}$ Recent studies suggest that children are just as likely as adults to become infected with SARS-CoV-2 but have fewer symptoms and lower case fatality rates. ${ }^{9}{ }^{10}$ Considering public health policy implications, more studies on the epidemiology of SARSCoV-2 infections are needed along with data on the clinical outcome of COVID-19 in children ${ }^{11}$ and the role of children in SARS-CoV-2 transmission. However, most data come primarily from higher income countries where rates of childhood obesity and diabetes may be higher, leading to disproportionately severe outcomes. The public health implications of the pandemic in small countries with limited resources remain underinvestigated and under-reported. The aim of this study was to capture key epidemiological data on SARSCoV-2 infection in Nicaraguan children and adolescents 18 years and younger ( $\leq 18$ years) seeking medical care to inform physicians, healthcare workers and decision makers on the impact of the pandemic in children and to provide a resource for paediatric health services planning and overall COVID-19 infection response.

\section{MATERIALS AND METHODS}

\section{Study population and data collection}

The Pediatrics COVID-19 Network was established to conduct this research in Managua, Nicaragua. This network is composed of 33 paediatricians from four hospitals and two clinics across the city. From 6 October to 16 November 2020 , study staff at participating hospitals and clinics recruited children and adolescents ( $\leq 18$ years) at the outpatient units by inviting parents/guardians to enrol their children in the study. Age was the only inclusion or exclusion criteria. All parents were approached for participation. Parents who showed interest in volunteering their children for the study were informed of the study's purpose and were asked to sign a form indicating informed consent. Children were recruited into a possible COVID-19 group based on symptoms, as judged by the individual clinician. Any children presenting with COVID-19 symptoms were generally considered possible COVID-19 cases. Clinicians looked for the following most commonly associated COVID-19 symptoms: fever, cough, sore throat, diarrhoea, headache, fatigue and myalgia. The full list of symptoms used to classify as probable COVID-19 case is in the study questionnaire (online supplemental file 1). A comparison group included children lacking any COVID-19 symptoms, who were all attending routine check-ups or seeking care for issues unrelated to COVID-19. The screening settings were the same for both the possible COVID-19 group and the comparison group. None of the study participants were asked about their possible exposure to the SARS-CoV-2 virus prior to recruitment. A total of 418 children were recruited. All children were tested for SARS-CoV-2 RNA through the loop-mediated isothermal amplification (LAMP) detection method as described previously. ${ }^{12}$

\section{Survey tool}

A questionnaire was employed to identify: (1) possible exposures or risk factors for infection, (2) current symptoms and (3) factors associated with vulnerability to severe illness and complications (age, sex and chronic medical conditions). The questionnaire also gathered data on school attendance, use of face masks, handwashing habits and presence of a family member with COVID-19 symptoms at home. Paediatricians filled out the questionnaires while interviewing parents and the children (online supplemental file 1 ).

\section{Specimen collection and testing}

Between 1 and $4 \mathrm{~mL}$ of saliva were self-collected by each study participant age 3 years and over in flasks containing $2 \mathrm{~mL}$ of sample buffer ${ }^{13}$ (1× phosphate buffered saline, $\mathrm{pH} 7$ ) for LAMP detection of SARS-CoV-2. LAMP detection has previously demonstrated $97.5 \%$ and a specificity of $99.7 \%$ for detection of SARS-CoV-2 infections. For children under 3 years of age, we used mouth swabs (Fisherbrand) designed to painlessly collect saliva for analysis. After collection, specimens were kept on ice and transported immediately to the laboratory for the detection of nucleic acids from SARS-CoV-2. Testing assays were performed on saliva samples without an RNA purification step within 1-2 hours following collection, as previously described. ${ }^{12}$ All LAMP reactions were performed following New England Biolab's (NEB) published protocol using WarmStart Colorimetric LAMP 2× Master 
Mix (NEB, M1800L). ${ }^{14} 15$ We used $20 \mu \mathrm{L}$ reactions consisting of $10 \mu \mathrm{L}$ of $2 \times$ master mix, $2 \mu \mathrm{L}$ of $10 \times$ primer mix targeting the viral genes $\mathrm{N}$ and $\mathrm{E}, 5 \mu \mathrm{L}$ nuclease-free water and $3 \mu \mathrm{L}$ samples (NEB E2019 COVID-19 LAMP kit). LAMP reactions were incubated at $65^{\circ} \mathrm{C}$ using an Applied Biosystems 2720 Thermal Cycler for 45 min. For quality control, we performed 20 additional saliva tests on individuals who had been diagnosed by quantitative reverse transcription PCR (qRT-PCR) using nasopharyngeal swabs at the central government laboratory. There was $100 \%$ concordance with the LAMP results. These 20 volunteers (12 SARS-CoV-2 positives and 8 SARS-CoV-2 negatives) were identified among university staff. Results were communicated to paediatricians within 6 hours via phone calls, who in turn conveyed the results, along with appropriate medical advice, to the corresponding parents or legal guardians.

\section{Clinical features in children}

Following the USA National Institutes of Health (NIH) COVID-19 Treatment Guidelines ${ }^{16}$ the illness severity of patients with COVID-19 was stratified into the following categories: asymptomatic or presymptomatic infection, mild, moderate, severe and critical illness. Asymptomatic or presymptomatic infection: individuals who test positive for SARS-CoV-2 using a virological test but who have no symptoms that are consistent with COVID-19. No symptoms: individuals who showed none of the key COVID-19 symptoms at the moment of testing. Participating paediatricians collected clinical information on cases using the survey tool, recording age, sex, underlying disease, date of diagnosis, risk factors for exposure, symptoms, laboratory test results, treatment and outcome. Twenty-five of those testing positive were followed for 21 days to determine clinical outcome.

\section{Statistical analysis}

All data were entered into a Microsoft Excel spreadsheet including results of SARS-CoV-2 detection using the LAMP assay, along with data obtained from the questionnaire. Prior to statistical analyses, all data were transferred to a spreadsheet without linkage to the original database, eliminating all personal identification data. We identified the proportion positive in the two recruitment groups: symptoms/no symptoms. Participants were categorised by group: symptomatic and no symptoms and further divided by SARS-CoV-2 infection result from the LAMP assay. For some analyses, all four strata were maintained, and in others, we grouped by infection status. All analyses were conducted using SAS V.9.4.

Proportion of positive tests were compared by age, sex and symptom presentation. Pearson $\chi^{2}$ tests were conducted to identify differences in the distribution of age, sex and presentation (symptoms/no symptoms) in children with positive versus negative test results. ORs were estimated to: (1) compare symptoms between children with negative versus positive tests overall and by age group, (2) identify ORs of symptomatic versus children with no symptoms who tested positive and (3) to examine associations between social factors for those with positive versus negative LAMP tests. ORs were estimated using logistic regression modelling. Models of social factors associated with positive and negative tests were stratified by children with and without symptoms and were adjusted for age and sex.

\section{Patient and public involvement}

Patients and members of the public were not directly involved in the design and conduct of this study. The publication of this study will be shared with all participants, and links to this work will be included on the institutional website.

\section{RESULTS}

In this cross-sectional study, we included 418 children and adolescents under the age of 18 years with a nearly equal sample of males (206/49\%) and females (212/51\%). More than half of the participating children were $\leq 5$ years of age. Children were recruited into two distinct groups: children presenting with COVID-19 symptoms and children without COVID-19 symptoms and further divided by SARS-CoV-2 infection result from the LAMP assay (figure 1). The demographic characteristics of study participants are summarised in table 1 .

\section{SARS-CoV-2 prevalence}

A total of 181 children (43.3\%) tested positive for SARSCoV-2. A percentage of 74.6 (135 of 181) were symptomatic and 25.4\% (46 of 181) were asymptomatic carriers.

We examined infection rates among participants in three different age groups: $0-5,6-11$ and $12-18$ years. Within the $\leq 5$ age group, 109 children $(45.6 \%)$ were SARS-CoV-2 positive, while in the $6-11$ and $12-18$ age groups, $46(40 \%)$ and $26(40.6 \%)$ tested positive, respectively (table 1). In the comparison group of children with no symptoms, 46 children $(46.5 \%)$ were SARS-CoV-2 positive. The youngest SARS-CoV-2 patient identified was 21 days old. Girls (105 of $212(49.5 \%)$ ) had higher prevalence of SARS-CoV-2 infection than boys (76 of 206 $(36.9 \%) ; \mathrm{p}=0.009)$ (table 1).

\section{Clinical presentation of children}

The most common symptoms reported by those testing positive for SARS-CoV-2 were fever $(\mathrm{n}=83 ; 61.5 \%)$ and cough $(\mathrm{n}=82 ; 60.7 \%)$ (table 2). Symptomatic children who tested positive for SARS-CoV-2 were 2.7 times more likely to have diarrhoea (26.7\% in positive vs $12 \%$ in negative; $\mathrm{OR}=2.7$ (95\% CI 1.5 to 4.8$), \mathrm{p}=0.001$ ) and were 2.0 times more likely to have myalgia $(17.8 \%$ in positive vs $9.8 \%$ in negative; OR=2.0 (95\% CI 1.0 to 3.8), $\mathrm{p}=0.04$ ). They were also less likely to have sore throat ( $20 \%$ in positive vs $29.4 \%$ in negative; $\mathrm{OR}=0.6$ (95\% CI 0.4 to 1.0 ), $\mathrm{p}=0.06$ ). Analysis of symptoms associated with a positive SARS-CoV-2 test across the age groups demonstrated similar patterns. Diarrhoea presented more commonly in 


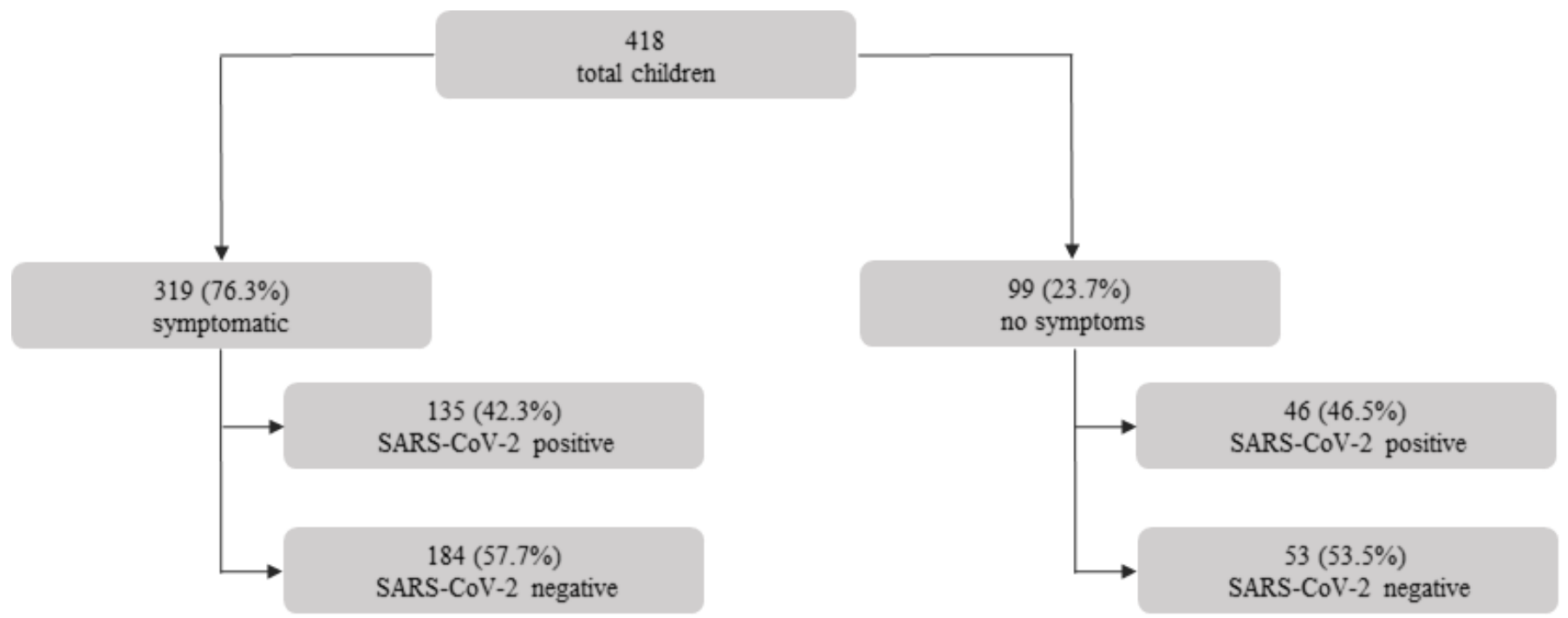

Figure 1 Flow chart of study participants and SARS-CoV-2 infection status.

all age groups for those positive for SARS-CoV-2 (table 3) though this did not reach significance in the oldest age group ( $\mathrm{p}=0.19$ ). Conjunctivitis was positively associated with a positive SARS-CoV-2 result in children under age 5 years, but not in other age groups. Children who tested positive for SARS-CoV-2 that had symptoms were more likely to be under age 5 years $(\mathrm{OR}=11.1$ (95\% CI 4 to $31.1), \mathrm{p}<0.0001)$ and have a pre-existing comorbid condition $(\mathrm{OR}=2.6(95 \%$ CI 1.0 to 6.7$), \mathrm{p}=0.04$ (table 4$)$.

In our study, $97(23.2 \%)$ out of the 418 enrolled children had at least one pre-existing chronic underlying disease and several had an association of two or more chronic conditions. Among the 319 symptomatic children, the most common comorbidity was respiratory disease $(n=40 ; 12.5 \%)$ (table 2$)$. Other important chronic diseases were heart disease $(n=12 ; 3.8 \%)$ and obesity $(n=6$; $1.9 \%$ ). Children with pre-existing cardiovascular disease that presented with symptoms were 7.3 times more likely to test positive for SARS-CoV-2 (OR=7.3 (95\% CI 1.6 to
33.8), $\mathrm{p}=0.01$ ). Furthermore, data in table 4 indicate that within positive children, those who had comorbidities were more likely to be in the group with symptoms $\mathrm{OR}=2.6(95 \%$ CI 1.0 to 6.7$) \mathrm{p}=0.04$.

\section{Clinical course of the disease}

Among all SARS-CoV-2 confirmed cases, the paediatrics network was able to follow-up the clinical course of the disease for 25 ( $14 \%$ of test positive) children (online supplemental file 2). Out of these 25 children, severity of illness was reported as mild for $12(48 \%)$, moderate for $12(48 \%)$ and severe for 1 (4\%). Fifteen of these children presented underlying medical conditions that put them at increased risk for severe illness from COVID19 . The youngest group $(\leq 5)$ represented the majority of mild $(67 \%)$ and moderate $(75 \%)$ cases, whereas the only severe case reported was within the $6-11$ years age group. Overall, seven (4\%) children were hospitalised

Table 1 Demographic data of children enrolled in the study and SARS-CoV-2 test results, $n=418$

\begin{tabular}{|c|c|c|c|c|}
\hline Category & Total & $\begin{array}{l}\text { Positive test } \\
\mathrm{n}=181, \mathrm{n}(\%)\end{array}$ & $\begin{array}{l}\text { Negative test } \\
\mathrm{n}=237,(\%)\end{array}$ & $X^{2}(\mathrm{df}, N=)=, p$ value \\
\hline \multicolumn{5}{|l|}{ Age, years } \\
\hline $6-11$ & 115 & $46(40)$ & $69(60)$ & \multirow{2}{*}{$X^{2} 1.2, p$ value $=0.54$} \\
\hline $12-18$ & 64 & $26(40.6)$ & 38 (59.3) & \\
\hline Female & 212 & $105(49.5)$ & $107(50.5)$ & $X^{2} 6.8, p$ value $=0.009$ \\
\hline \multicolumn{5}{|l|}{ Symptom history } \\
\hline No symptoms & 99 & $46(46.5 \%)$ & 53 (53.5) & \multirow[t]{2}{*}{$X^{2} 0.53, p$ value $=0.47$} \\
\hline Symptoms & 319 & $135(42.3 \%)$ & $184(57.7)$ & \\
\hline
\end{tabular}

Bold values are considered statistically significant.

${ }^{*}$ Pearson $X^{2}$ and $p$ values compares the distribution of age, sex and symptoms by positive and negative test results. 
Table 2 Symptoms and comorbidities of children and SARS-CoV-2 test results for those presenting with COVID-19 like symptoms

\begin{tabular}{|c|c|c|c|c|c|}
\hline & Total & Positive & Negative & \multirow[b]{2}{*}{ OR $(95 \% \mathrm{Cl})$} & \multirow[b]{2}{*}{$P$ value for $O R$} \\
\hline & $\mathrm{n}=319(76.3 \%)$ & $\mathrm{n}=135(42.3 \%)$ & $n=184(57.7 \%)$ & & \\
\hline \multicolumn{6}{|c|}{ Screening symptoms distribution, $\mathrm{n}(\%)$} \\
\hline Fever & $190(59.6)$ & $83(61.5)$ & $107(58.2)$ & $1.1(0.8$ to 1.4$)$ & 0.55 \\
\hline Cough & $190(59.6)$ & $82(60.7)$ & $108(58.7)$ & $1.1(0.7$ to 1.7$)$ & 0.71 \\
\hline Rhinorrhoea & $125(39.2)$ & $57(42.2)$ & $68(37.0)$ & $1.0(0.6$ to 1.6$)$ & 0.95 \\
\hline Sore throat & $81(25.4)$ & $27(20)$ & $54(29.4)$ & 0.6 (0.4 to 1.0$)$ & 0.06 \\
\hline Diarrhoea & $58(18.2)$ & $36(26.7)$ & $22(12.0)$ & 2.7 (1.5 to 4.8$)$ & 0.001 \\
\hline Headache & $58(18.2)$ & $22(16.3)$ & $36(19.6)$ & $0.8(0.4$ to 1.4$)$ & 0.46 \\
\hline Asthenia & $53(16.6)$ & $22(16.3)$ & $31(16.8)$ & $1.0(0.5$ to 1.7$)$ & 0.90 \\
\hline Myalgia & $42(13.2)$ & $24(17.8)$ & $18(9.8)$ & 2.0 (1.0 to 3.8$)$ & 0.04 \\
\hline Vomiting & $21(6.6)$ & $9(6.7)$ & $12(6.5)$ & $1.1(0.3$ to 3.8$)$ & 0.83 \\
\hline $\begin{array}{l}\text { Difficulty breathing or } \\
\text { shortness of breath }\end{array}$ & $16(5.0)$ & $7(5.2)$ & $9(4.9)$ & $1.1(0.4$ to 2.9$)$ & 0.90 \\
\hline Loss of taste & $5(1.6)$ & $3(2.2)$ & $2(1.1)$ & 2.1 (0.3 to 12.6$)$ & 0.42 \\
\hline Loss of smell & $3(0.9)$ & $2(1.5)$ & $1(0.5)$ & $2.8(0.2$ to 30.7$)$ & 0.41 \\
\hline \multicolumn{6}{|l|}{ Other symptoms } \\
\hline Skin rash & $13(4.1)$ & $7(5.2)$ & $6(3.3)$ & $1.6(0.5$ to 4.9$)$ & 0.39 \\
\hline Conjunctivitis & $10(3.1)$ & $7(5.2)$ & $3(1.6)$ & 3.3 (0.8 to 13.0$)$ & 0.08 \\
\hline Chest pain or pressure & $10(3.1)$ & $4(3.0)$ & $6(3.3)$ & 0.9 (0.3 to 3.3$)$ & 0.88 \\
\hline $\begin{array}{l}\text { Loss of colour on the fingers } \\
\text { of the hands or feet }\end{array}$ & $3(0.9)$ & $1(0.7)$ & $2(1.1)$ & 0.7 (0.1 to 7.6$)$ & 0.75 \\
\hline Loss of speech and movement & $1(0.3)$ & $1(0.7)$ & $0(0)$ & nd & \\
\hline \multicolumn{6}{|l|}{ Comorbidities } \\
\hline Respiratory diseases & $40(12.5)$ & $21(15.6)$ & 19 (10.3) & $1.6(0.8$ to 3.1$)$ & 0.17 \\
\hline Cardiovascular diseases & $12(3.8)$ & $10(7.4)$ & $2(1.1)$ & 7.3 (1.6 to 33.8$)$ & 0.01 \\
\hline Obesity & $6(1.9)$ & $3(2.2)$ & $3(1.6)$ & $1.4(0.3$ to 6.9$)$ & 0.70 \\
\hline Cancer & $1(0.3)$ & $0(0)$ & $1(0.5)$ & nd & \\
\hline Kawasaki disease & $1(0.3)$ & $1(0.7)$ & $0(0)$ & nd & \\
\hline
\end{tabular}

$P$ values for the bivariate models are indicated in the rightmost column.

Bold values are considered statistically significant.

*ORs generated using logistic regression modelling with 95\% Cl.

nd, not determined.

with COVID-19, including two (1\%) that were admitted to the intensive care unit (ICU). No patient died.

\section{Contact with suspected COVID-19 cases}

Seventy-nine (19\%) out of the 418 enrolled children reported having at least one family member with COVID-19 symptoms at home (table 5). Of those, 48 were females $(61 \%)$ and 31 males $(39 \%)$. In children without symptoms, those with a family member currently sick at home were 2.8 times more likely to test positive for SARSCoV-2 (OR=2.8 (95\% CI 1.1 to 6.7), $\mathrm{p}=0.03$ ). Out of those that reported at least one family member with COVID-19 symptoms, $43.0 \%(\mathrm{n}=34)$ resulted SARS-CoV-2 positive, 14 symptomatic and 20 without any symptoms. Among females who reported having a family member with COVID-19 symptoms, $45.8 \%$ ( $\mathrm{n}=22$ ) resulted SARS-CoV-2 positive, including 8 symptomatic and 14 asymptomatic females, whereas among males, $38.7 \% \quad(n=12)$ resulted positive, six symptomatic and six asymptomatic males. Nearly half of families reported having had a family member with suspected COVID-19 in the past (41\%) with fewer reporting knowing individuals sick at school (19\%), work $(21 \%)$ or in the neighbourhood $(22 \%)$.

\section{Outside activities and SARS-CoV-2 infection}

One hundred and thirty-three children (32\%) were reported attending school in person during the study period (table 5), 73 females (55\%) and 60 males (45\%). Out of the 73 females that attended school, 28 (38\%) resulted SARS-CoV-2 positive. Among the 60 males reported to attend school in person, $18(30 \%)$ resulted SARS-CoV-2 positive. In children who presented with 
Table 3 Symptoms associated with a positive test by age group (reduced subset limited to factors $p<0.20$ )

\begin{tabular}{|c|c|c|c|c|c|}
\hline & Total, n (\%) & Positive, n (\%) & Negative, n (\%) & OR (95\% Cl) & $P$ value for OR \\
\hline Under age 5 years & $n=216$ & $n=100(46 \%)$ & $n=116(54 \%)$ & & \\
\hline Cough & $133(62)$ & $68(68)$ & $65(56)$ & 1.7 (9.6 to 2.9 ) & 0.07 \\
\hline Diarrhoea & 38 (18) & $24(24)$ & $14(12)$ & 2.3 (1.1 to 4.7 ) & 0.02 \\
\hline Myalgia & $24(11)$ & $15(15)$ & $9(8)$ & 2.1 (0.9 to 5.0$)$ & 0.09 \\
\hline Conjunctivitis & $7(3)$ & $5(5)$ & $2(2)$ & 3.0 (0.6 to 15.8$)$ & 0.19 \\
\hline $5-12$ years & $n=68$ & $\mathrm{n}=22(32 \%)$ & $\mathrm{n}=46(68)$ & & \\
\hline Cough & $40(59)$ & $10(45)$ & $30(65)$ & 0.4 (0.2 to 1.3$)$ & 0.12 \\
\hline Rhinitis & $21(31)$ & $4(18)$ & 17 (37) & 0.4 (0.1 to 1.3$)$ & 0.12 \\
\hline Sore throat & $32(47)$ & 7 (22) & 25 (54) & $0.4(0.1$ to 1.1$)$ & 0.09 \\
\hline Diarrhoea & $11(16)$ & $7(31)$ & $4(9)$ & 4.9 (1.3 to 19.1$)$ & 0.02 \\
\hline Age $>12$ years & $n=35$ & $\mathrm{n}=13(37)$ & $\mathrm{n}=22(63)$ & & \\
\hline Cough & $17(49)$ & $4(31)$ & $13(59)$ & 0.3 (0.1 to 1.3$)$ & 0.11 \\
\hline Rhinitis & $8(23)$ & $1(8)$ & $7(32)$ & 0.2 (0.02 to 1.7$)$ & 0.13 \\
\hline Diarrhoea & $9(26)$ & $5(38)$ & $4(18)$ & 2.8 (0.6 to 13.3$)$ & 0.19 \\
\hline Myalgia & $9(26)$ & $5(38)$ & $4(18)$ & $2.8(0.6$ to 13.3$)$ & 0.19 \\
\hline
\end{tabular}

Bold values are considered statistically significant.

symptoms, those who went to school were less likely to test positive for SARS-CoV-2 than those not in school $(\mathrm{OR}=0.8$ (95\% CI 0.6 to 1.0$), \mathrm{p}=0.08)$. This association was not noted in children who were presenting without symptoms $(\mathrm{OR}=1.2(95 \% \mathrm{CI} 0.8$ to 2.0$), \mathrm{p}=0.40)$.

Regarding the use of transportation to get to school, $117(80.7 \%)$ children reported using private family vehicles, $12(8.3 \%)$ walked to school and $16(11 \%)$ children used public transportation. Among those children transported to school in private family vehicles, $37(31.6 \%)$ were SARS-CoV-2 positive, including 28 symptomatic and
9 asymptomatic children. Among children who walked to school, three $(25 \%)$ were SARS-CoV-2 positive. Out of 16 children that used public transportation to get to school, $12(75 \%)$ were SARS-CoV-2 positive (six symptomatic and six asymptomatic children). In children who presented with symptoms, those who rode in the family car or walked were 0.1 time as likely to test positive for SARS-CoV-2 when compared with those who rode public or school buses $(\mathrm{OR}=0.1$ (95\% CI 0.1 to 0.8$), \mathrm{p}=0.03$ ) (table 5).

Table 4 Factors associated with having symptoms in those that have a SARS-CoV-2 positive test

\begin{tabular}{|c|c|c|c|c|}
\hline & Symptoms $(n=135)$ & No symptoms $(n=46)$ & OR $(95 \% \mathrm{Cl})$ & $P$ value \\
\hline \multicolumn{5}{|l|}{ Sex, n (\%) } \\
\hline Male & $59(77)$ & $17(23)$ & 1.3 (0.7 to 2.6$)$ & 0.42 \\
\hline Female & $76(72)$ & $29(28)$ & ref & \\
\hline \multicolumn{5}{|l|}{ Age group (years), n (\%) } \\
\hline$\leq 5$ & $100(92)$ & $9(8)$ & 11.1 (4.0 to 31.1$)$ & $<0.0001$ \\
\hline $5-11$ & $22(48)$ & $24(52)$ & 0.9 (0.4 to 2.4$)$ & 0.86 \\
\hline $12-18$ & $13(50)$ & $13(50)$ & ref & \\
\hline \multicolumn{5}{|l|}{ Comorbidities, n (\%) } \\
\hline Any comorbidity & $38(86)$ & $6(14)$ & 2.6 (1.0 to 6.7$)$ & 0.04 \\
\hline Respiratory diseases & $21(88)$ & $3(13)$ & 2.6 (0.7 to 9.3$)$ & 0.13 \\
\hline Cardiovascular diseases & $10(100)$ & $0(0)$ & nd & \\
\hline Obesity & $3(100))$ & $0(0)$ & nd & \\
\hline
\end{tabular}

$P$ values for the bivariate models are indicated in the rightmost column.

Bold values are considered statistically significant.

${ }^{*}$ OR generated using logistic regression models with $95 \% \mathrm{Cl}$.

$\mathrm{N}$, sample size; nd, not determined. 
Table 5 Social factors related to positive tests for children presenting with symptoms and those without symptoms

\begin{tabular}{|c|c|c|c|c|c|c|c|}
\hline $\begin{array}{l}\text { Exposure } \\
\text { variable ( } \mathrm{n}=\text { total, } \\
\text { asymptomatic, } \\
\text { symptomatic) }\end{array}$ & $\begin{array}{l}\text { Reporting } \\
\text { exposure (n, } \\
\%)\end{array}$ & \multicolumn{3}{|l|}{ No symptoms } & \multicolumn{3}{|l|}{ Symptoms } \\
\hline \multicolumn{8}{|c|}{ Suspected contact with individuals infected with COVID-19 } \\
\hline $\begin{array}{l}\text { Family member } \\
\text { currently sick } \\
\left(n=418^{t}, 319^{s} \text {, }\right. \\
\left.99^{n}\right)\end{array}$ & $79(19)$ & $20(43)$ & $11(21)$ & $\begin{array}{l}2.8(1.1 \\
\text { to } 6.7) \\
p=0.03\end{array}$ & $14(10)$ & $34(18)$ & $\begin{array}{l}0.5(0.4 \text { to } 1.0) \\
p=0.05\end{array}$ \\
\hline $\begin{array}{l}\text { Family member } \\
\text { history of } \\
\text { suspected of } \\
\text { COVID }\left(n=418^{t}\right. \\
\left.319^{s}, 99^{n}\right)\end{array}$ & $172(41)$ & $24(52)$ & $29(55)$ & $\begin{array}{l}0.9(0.4 \\
\text { to } 1.9) \\
\mathrm{p}=0.69\end{array}$ & $55(41)$ & $64(35)$ & $\begin{array}{l}1.4(0.9 \text { to } 2.2) \\
p=0.19\end{array}$ \\
\hline $\begin{array}{l}\text { Knows sick } \\
\text { people at work } \\
\left(n=347^{t}, 266^{s},\right. \\
\left.81^{n}\right)\end{array}$ & $74(21)$ & $11(28)$ & $5(12)$ & $\begin{array}{l}2.9(0.9 \\
\text { to } 9.6) \\
p=0.07\end{array}$ & $22(20 \%)$ & $36(23)$ & $\begin{array}{l}0.9(0.5 \text { to } 1.7) \\
p=0.77\end{array}$ \\
\hline $\begin{array}{l}\text { Knows sick } \\
\text { people in } \\
\text { neighbourhood } \\
\left(n=365^{t}, 276^{s}\right. \\
\left.89^{n}\right)\end{array}$ & $82(22)$ & $10(24)$ & $15(32)$ & $\begin{array}{l}0.6(0.2 \\
\text { to } 1.7) \\
p=0.37\end{array}$ & $22(19)$ & $35(22)$ & $\begin{array}{l}0.9(0.5 \text { to } 1.7) \\
p=0.88\end{array}$ \\
\hline
\end{tabular}

Household characteristics

\begin{tabular}{|c|c|c|c|c|c|c|c|}
\hline \multicolumn{8}{|c|}{ Family size $\left(n=399^{t}, 305^{s}, 94^{n}\right)$} \\
\hline 1-3 people & 55 (13) & 7 (15) & $12(23)$ & ref & $11(8)$ & $25(14)$ & ref \\
\hline 4-6 people & $263(63)$ & 27 (59) & 34 (64\%) & $\begin{array}{l}1.3(0.4 \text { to } \\
3.8) p=0.64\end{array}$ & $85(63)$ & 117 (64) & $\begin{array}{l}1.8(0.8 \text { to } 4.0) \\
p=0.12\end{array}$ \\
\hline$>6$ people & $100(24)$ & $12(26)$ & $7(13)$ & $\begin{array}{l}2.6(.7 \text { to } \\
9.9) \mathrm{p}=0.16\end{array}$ & 39 (29) & $42(23)$ & $\begin{array}{l}2.2(0.9 \text { to } 5.1) \\
p=0.07\end{array}$ \\
\hline $\begin{array}{l}\text { Any children } \\
\text { attending school } \\
\left(n=364^{t}, 277^{s},\right. \\
\left.87^{n}\right)\end{array}$ & $147(40)$ & $16(40)$ & $16(34)$ & $\begin{array}{l}1.4(.5 \\
\text { to } 3.5) \\
p=0.51\end{array}$ & $38(33)$ & 77 (48) & $\begin{array}{l}0.6(0.4 \text { to } 1.0), \\
p=0.04\end{array}$ \\
\hline
\end{tabular}

Outside activities

\begin{tabular}{|c|c|c|c|c|c|c|c|}
\hline $\begin{array}{l}\text { Child attends } \\
\text { school }\left(n=412^{t} \text {, }\right. \\
\left.313^{s} 99^{n}\right)\end{array}$ & $133(32)$ & $16(35)$ & $15(28)$ & $\begin{array}{l}1.2(0.8 \text { to } \\
2.0) p=0.40\end{array}$ & $30(23)$ & $72(40)$ & $\begin{array}{l}0.8(0.6 \text { to } 1.0) \\
p=0.08\end{array}$ \\
\hline
\end{tabular}
$\left.313^{s}, 99^{n}\right)$

\begin{tabular}{|c|c|c|c|c|c|c|c|}
\hline \multicolumn{8}{|c|}{ Family school transport $\left(n=145^{t}, 111^{s}, 34^{n}\right)$} \\
\hline $\begin{array}{l}\text { Car/walking } \\
\text { versus }\end{array}$ & $129(89)$ & $11(65)$ & $15(88)$ & \multirow{2}{*}{$\begin{array}{l}0.2(0.1 \\
\text { to } 1.5) \\
\mathrm{p}=0.13\end{array}$} & $29(83)$ & $74(97)$ & \multirow[t]{2}{*}{$\begin{array}{l}0.1(0.1 \text { to } 0.8) \\
p=0.03\end{array}$} \\
\hline $\begin{array}{l}\text { Bus (public or } \\
\text { school) }\end{array}$ & $16(11)$ & $6(35)$ & $2(12)$ & & $6(17)$ & $2(3)$ & \\
\hline
\end{tabular}

Number of people who work outside home $\left(n=383^{t}, 291^{s}, 92^{n}\right)$

\begin{tabular}{|c|c|c|c|c|c|c|c|}
\hline $0-1$ & $172(45)$ & 22 (52) & $26(48)$ & $\begin{array}{l}1.0(0.2 \text { to } \\
4.6), p=1.0\end{array}$ & 48 (38) & 79 (48) & $\begin{array}{l}0.6(0.3 \text { to } 1.0) \\
p=0.05\end{array}$ \\
\hline 2 & 149 (39) & $20(48)$ & $21(5 \%)$ & $\begin{array}{l}0.8(0.2 \\
\text { to } 3.8) \\
p=0.80\end{array}$ & $41(33)$ & 62 (38) & $\begin{array}{l}0.6(0.3 \text { to } 1.1) \\
p=0.09\end{array}$ \\
\hline
\end{tabular}

Continued 
Table 5 Continued

\begin{tabular}{|c|c|c|c|c|c|c|c|}
\hline \multirow{2}{*}{$\begin{array}{l}\text { Exposure } \\
\text { variable ( } \mathrm{n}=\text { total, } \\
\text { asymptomatic, } \\
\text { symptomatic) }\end{array}$} & \multirow[b]{2}{*}{$\begin{array}{l}\text { Reporting } \\
\text { exposure (n, } \\
\%)\end{array}$} & \multicolumn{3}{|l|}{ No symptoms } & \multicolumn{3}{|l|}{ Symptoms } \\
\hline & & $\begin{array}{l}\text { SARS-CoV-2 } \\
\text { positive }(n, \%)\end{array}$ & $\begin{array}{l}\text { SARS CoV-2 } \\
\text { negative (n, } \\
\%)\end{array}$ & $\begin{array}{l}\text { OR* }^{*}(95 \% \\
\mathrm{Cl})\end{array}$ & $\begin{array}{l}\text { SARS CoV-2 } \\
\text { positive (n, } \\
\%)\end{array}$ & $\begin{array}{l}\text { SARS CoV- } \\
2 \text { negative } \\
(n, \%)\end{array}$ & OR* $^{\star}(95 \% \mathrm{Cl})$ \\
\hline 3 or more & $62(16)$ & $1(1)$ & $0(0)$ & ref & 37 (29) & $24(15)$ & ref \\
\hline $\begin{array}{l}\text { Many activities } \\
\text { outside home } \\
\left(n=329^{t}, 245^{s}\right. \\
\left.84^{n}\right)\end{array}$ & $162(49)$ & $15(35)$ & $16(39)$ & $\begin{array}{l}1.1(0.4 \\
\text { to } 2.8) \\
p=0.82\end{array}$ & $58(55)$ & $73(53)$ & $\begin{array}{l}1.1(0.7 \text { to } 1.9) \\
p=0.66\end{array}$ \\
\hline \multicolumn{8}{|l|}{ Prevention behaviours } \\
\hline $\begin{array}{l}\text { Child wears a } \\
\text { mask }\left(n=366^{t}\right. \\
\left.277^{s}, 89^{n}\right)\end{array}$ & $216(59)$ & $29(67)$ & $37(80)$ & $\begin{array}{l}0.5(0.2 \\
\text { to } 1.4) \\
p=0.19\end{array}$ & $49(41)$ & $101(64)$ & $\begin{array}{l}0.4(0.2 \text { to } 0.7) \\
p=0.001\end{array}$ \\
\hline $\begin{array}{l}\text { Tutors wears a } \\
\text { mask }\left(n=407^{t}\right. \\
\left.310^{s}, 97^{n}\right)\end{array}$ & $376(92)$ & $44(98)$ & $48(92)$ & $\begin{array}{l}4.2(0.4 \\
\text { to } 40.2) \\
p=0.21\end{array}$ & $116(87)$ & $168(95)$ & $\begin{array}{l}0.3(0.1 \text { to } 0.7) \\
p=0.005\end{array}$ \\
\hline $\begin{array}{l}\text { Visitors wear a } \\
\text { mask }\left(n=397^{t}\right. \\
\left.299^{s}, 98^{n}\right)\end{array}$ & $207(52)$ & $25(54)$ & $33(63)$ & $\begin{array}{l}0.6(0.3 \\
\text { to } 1.5) \\
p=0.18\end{array}$ & $64(51)$ & $85(49)$ & $\begin{array}{l}1.0(0.6 \text { to } 1.6), \\
p=0.91\end{array}$ \\
\hline $\begin{array}{l}\text { Family physically } \\
\text { distances when } \\
\text { visits }\left(n=351^{t}\right. \\
\left.264^{\mathrm{s}}, 87^{\mathrm{n}}\right)\end{array}$ & 124 (35) & $21(55)$ & $27(55)$ & $\begin{array}{l}1.0(0.4 \\
\text { to } 2.4) \\
p=0.98\end{array}$ & $31(12)$ & $45(30)$ & $\begin{array}{l}0.9(0.5 \text { to } 1.6) \\
p=0.78\end{array}$ \\
\hline
\end{tabular}

Bold values are considered statistically significant.

${ }^{*}$ Age-adjusted and sex-adjusted ORs with $95 \% \mathrm{Cl}$, \% use sample size as denoted in column 1 (t=total sample size for that variable, s=sample size for the symptomatic children, $n=$ sample size for the non-symptomatic children), proportion is for the total that answered 'yes' to the factor of interest or the categories as noted. ORs for a positive test were calculated using the 'no' response as reference.

Out of the 418 enrolled children, 219 children (113 (51.6\%) females and $106(48.4 \%)$ males), reported having activities outside of their homes, including visiting families and friends, birthday parties, shopping and attending church activities. Ninety-four $(42.9 \%)$ of those reporting activities outside the home tested SARS-CoV-2 positive; 52 $(55.3 \%)$ females versus 42 males $(44.7 \%)$ resulted positive for COVID-19. Furthermore, out of the 162 children that reported having frequent activities outside their homes, $73(45 \%)$ tested SARS-CoV-2 positive, 58 (55\%) symptomatic and 15 (35\%) non-symptomatic children. Though there was no significant association between reporting having many activities outside the home and testing positive for SARS-CoV-2 (table 5).

\section{Prevention strategies}

A total of $216(59.0 \%)$ children were reported using face masks frequently (104 males and 112 females). Among females who reported wearing face masks frequently, 49 $(43.8 \%)$ tested SARS-CoV-2 positive. In the case of males, $29(27.9 \%)$ of those who used face masks frequently tested SARS-CoV-2 positive. Among children who demonstrated symptoms of illness, children who wore a face mask were 0.4 times as likely to test positive for SARS-CoV-2 (OR=0.4 (95\% CI 0.2 to 0.7$), \mathrm{p}=0.001)$; a similar trend was seen in those who had no symptoms, but it did not reach significance $(\mathrm{OR}=0.5$ (95\% CI 0.2 to 1.4$), \mathrm{p}=0.19)$. Mask wearing was reported less frequently for the entire family with $44 \%$ of families overall wearing masks. Tutors were 
reported as wearing masks most frequently, with $92 \%$ of tutors reported as wearing a mask overall. Having a tutor wear a mask was associated with a reduced risk of SARS$\mathrm{CoV}-2$ infection in children with symptoms $(\mathrm{OR}=0.3(95 \%$ CI 0.1 to 0.7$) \mathrm{p}=0.005$ ). There was no association in children without symptoms. Visitors were reported as wearing masks about half the time (52\%) and was not associated with children testing positive in either group. Physical distancing was reported less frequently than wearing a mask with 124 (35\%) of individuals indicating family physically distances when visiting. This was somewhat higher for visitors with 162 (46\%) physically distancing when visiting. Approximately half $(\mathrm{n}=187,49 \%)$ of participants indicated that they talk with their neighbours about COVID-19.

\section{DISCUSSION}

\section{Principal findings}

There are five significant findings from our study: (1) there was a high prevalence of SARS-CoV-2 infection during the study period; SARS-CoV-2 was detected in $43.3 \%$ of the total number of enrolled children, including in $46.5 \%$ of the children without symptoms, suggesting that the infection may be widespread among Nicaraguan children; (2) the younger age group of $\leq 5$ years showed higher prevalence $(45.6 \%)$ of SARS-CoV-2 infection than the other two age groups (6-11 and 12-18 years), and similarly, girls had a higher prevalence than boys $(49.5 \%$ vs $36.9 \%$ ) throughout all age groups; (3) out of those that reported at least one family member with COVID-19 symptoms, $43.0 \%$ resulted SARS-CoV-2 positive; (4) about half $(46.5 \%)$ of the children were asymptomatic and $23 \%$ had at least one pre-existing chronic underlying disease; and (5) social distancing measures and wearing face masks showed a strong protective effect in significantly reducing infection in children.

\section{Comparison with other studies}

The high level of prevalence of SARS-CoV-2 infection among children in our study follows a similar pattern often detected during peaks in the pandemic curve and may be associated with higher incidence of COVID-19 in the general population, as children are as likely to become infected as adults. ${ }^{9}$ Data from a high-incidence setting in India showed positivity rates ranged between $33 \%$ and $40 \% .{ }^{17}$ Cases there had a younger age distribution compared with higher income countries. High COVID-19 prevalence relative to the population size was also estimated for Peru (31\%), Mexico (27\%) and Brazil $(22 \%) .^{18}$

Several studies have indicated that very young children may experience more severe illness. ${ }^{19}{ }^{20}$ Although it is hard to know for sure why the younger children in our study had the highest prevalence and were more likely to have symptoms of illness, it may be explained from children's habits at home. Infected household members are a major risk factor for paediatric COVID-19 $\operatorname{cases}^{2122}$ and was associated with a higher risk of infection in children in this study as well. Furthermore, the sources of infection for most children and youths appear to be family members and not schools, as demonstrated in a Hong Kong cross-sectional study. ${ }^{23}$

A significant percentage $(46.5 \%)$ of the children were asymptomatic carriers, which is consistent with the available evidence. Recent publications suggest that approximately $20 \%$ of SARS-CoV-2 infected children are asymptomatic, although the prevalence may be as high as $50 \%{ }^{24-26}$ However, it is difficult to establish the exact incidence of asymptomatic SARS-CoV-2 infection, especially when testing is limited. ${ }^{26}$ Surprisingly, the symptom most associated with having SARS-CoV-2 infection in the children who presented with symptoms was diarrhoea and myalgia, not respiratory symptoms. A study of symptomology in the UK also indicated that diarrhoea was a key predictor of SARS-CoV-2 infection in children, ${ }^{25}$ and common gastrointestinal symptoms have been reported in COVID-19 infected children. ${ }^{27}$

Our results do not conflict with current findings by others that COVID-19 is largely a mild disease in children under 19 years, including infants. ${ }^{19}{ }^{20} 28-30$ However, comorbidities are considered a significant risk factor for requiring ICU admission. ${ }^{20}$ In our study, $23 \%$ of the enrolled children had at least one comorbidity, the most common being respiratory illness (12.5\%), which was slightly higher among SARS-CoV-2 positive children $(15.6 \%)$. Heart disease appears to be an important risk factor for testing positive for SARS-CoV-2 (7.4\% vs $1.1 \%$, $\mathrm{OR}=7.3(95 \%$ CI 1.6 to 33.8$), \mathrm{p}=001)$. Individuals with comorbidities who tested positive were also more likely to be in the symptomatic group of children.

There was a significant association between taking public transportation or school buses to school and infection. Consequently, the use of public transportation may have contributed to the spread of the virus among children. In this study, we found a strong protective effect of masks against SARS-CoV-2 infection. However, children may have also been exposed at home during visits from extended family and friends who could have been SARSCoV-2 positive and who did not always use face masks nor practice social distancing to limit virus transmission. Accurate recall of consistent physical distancing may be challenging, particularly if interactions are frequent and is further complicated if interactions were indoors or outdoors, ${ }^{31}$ something that was not asked in the current study.

\section{Interpretation and potential implications of findings}

This is the first study providing data obtained from testing of SARS-CoV-2 infection in the Nicaraguan paediatric population, presenting evidence that fills a major research gap. We accomplished this by using a simple, highly sensitive detection technique (LAMP), which may be used in developing countries both as a detection method and for epidemiological surveillance, with a growing field of application variations. ${ }^{32-37}$ LAMP is faster and less cumbersome than 
qRT-PCR, and when used as a detection technique, LAMP has shown excellent sensitivity of up to $97.5 \%$ and specificity of up to $99.7 \%$ compared with qRT-PCR. ${ }^{38}{ }^{39}$ Such a degree of accuracy, with a fast turnaround time, is important for low-income countries such as Nicaragua that rely on a single government-controlled testing laboratory. Although it should be noted that, for infections with very low viral loads below the limit of detection, the LAMP method may return indeterminate or false-negative results. ${ }^{40}$ Furthermore, using saliva as the specimen to detect SARS-CoV-2 is a reliable method as it correlates well with clinical and immunological profiles. ${ }^{41}$ It is also less aerosol generating as compared with nasopharyngeal swabs or aspirate.

The high prevalence of SARS-CoV-2 infection found in children may point to widespread and sustained community transmission in Nicaragua. Our data highlight the importance of screening for SARS-CoV-2 in children, particularly in those who have an ill family member at home. In contrast to the rest of Central America, Nicaraguan authorities chose a path in complete opposition to the recommendations of the WHO, that is, leaving borders open, refusing to scale up testing and contact tracing and leaving all business and universities open. ${ }^{42}{ }^{43}$ All through the pandemic, the Nicaraguan government kept public schools open, and there were no restrictions imposed on transport and mobility. Preventive measures such as wearing face masks, social distancing and avoiding direct contact with suspected COVID-19 cases were not actively promoted. ${ }^{43}{ }^{44}$ It is critical that health authorities start implementing widespread frequent testing along with containment measures to diminish the widespread community transmission of SARS-CoV-2.

\section{Limitations of the study}

The study's data may not reflect the national prevalence of SARS-CoV-2 among Nicaraguan children since most children were from Managua, the capital of Nicaragua, although all individuals visiting these practices were eligible for inclusion and provide a fairly representative sample of children attending the participating clinics. Also, it is possible that some individuals were more likely to participate if they had a history of close contact with confirmed cases. However, a minority of people reported being in contact with individuals who were ill, suggesting this was not the primary motivating factor for participation. Results related to risk factors and exposures may be limited by the cross-sectional design. Children who had no symptoms at the time of clinic visit, who tested positive, may have developed symptoms later. Participant responses to surveys are subject to misclassification and recall bias. Recall bias is minimised, however, as neither the provider nor the participants were aware of their child's infection status at time of interview. Given the cross-sectional nature of the study, it is not possible to know if some children had lower chance of infection by attending school or if they had already been infected and recovered. While acknowledging these limitations, we conclude, based on the currently available data, that the prevalence of SARS-CoV-2 among Nicaraguan children was high during the time of this study.

\section{Conclusions}

To our knowledge, this is the first study to highlight the significantly high SARS-CoV-2 prevalence among Nicaraguan children, suggesting widespread and sustained community transmission, which further underscores the need for producing robust data on the true extent of SARSCoV-2 infection in Nicaragua. With no available vaccine for children, the lack of testing is a key barrier to the fight against the virus in Nicaragua. We provide important evidence that is of global interest for policy implications to help inform optimum paediatric health service planning and effective non-pharmaceutical interventions to reduce the rate of infection and to improve the overall COVID-19 disease response.

\section{Twitter Jorge A Huete-Pérez @jorgehuete}

Acknowledgements We thank Richard J. Roberts and New England Biolabs for donating reagents for this study. The authors would like to thank all physicians, members of the Pediatrics COVID-19 Network who contributed to the acquisition of data. Carlos Hernández contributed to study design and Cesar Victora made important suggestions to an earlier draft of this paper. We also thank the research team of the Molecular Biology Center, UCA, and Bryant Mendoza-Ramírez for helpful comments. We are grateful to all patients and their relatives for volunteering for this research. Institutional support and facilities were provided by the University of Central America, UCA, Nicaragua.

Contributors JAH-P conceived the study and its design, wrote the original draft of the manuscript, accepts full responsibility for the work and/or the conduct of the study, had access to the data, take responsibility for the integrity of the data and accuracy of the analysis and controlled the decision to publish. The manuscript's guarantor affirms that this manuscript is an honest, accurate and transparent account of the study being reported; that no important aspects of the study have been omitted; and that any discrepancies from the study as planned (and, if relevant, registered) have been explained. CC-R and LP-M contributed to data collection, organised and entered data. KCE contributed to statistical analyses and interpretation. SS contributed to data collection, analyses and interpretation. AH contributed to the study design, data analyses, and writing. All authors contributed to the final drafting of the manuscript and have seen and approved the submitted version of this manuscript.

Funding The authors have not declared a specific grant for this research from any funding agency in the public, commercial or not-for-profit sectors.

Competing interests None declared.

Patient consent for publication Not applicable.

Ethics approval Our study was conducted according to the principles expressed in the Declaration of Helsinki, was reviewed and approved by the Ethics Committee of the University of Central America (ID: WB-2020-10-23) and written research authorisation and informed consent was obtained from the parents or legal guardians of all participants.

Provenance and peer review Not commissioned; externally peer reviewed.

Data availability statement All data relevant to the study are included in the article or uploaded as supplementary information. The manuscript includes all methods, values and information needed to replicate the study, and the sources used are indicated. The whole database of the study is available upon request.

Supplemental material This content has been supplied by the author(s). It has not been vetted by BMJ Publishing Group Limited (BMJ) and may not have been peer-reviewed. Any opinions or recommendations discussed are solely those of the author(s) and are not endorsed by BMJ. BMJ disclaims all liability and responsibility arising from any reliance placed on the content. Where the content includes any translated material, BMJ does not warrant the accuracy and reliability of the translations (including but not limited to local regulations, clinical guidelines, terminology, drug names and drug dosages), and is not responsible for any error and/or omissions arising from translation and adaptation or otherwise.

Open access This is an open access article distributed in accordance with the Creative Commons Attribution Non Commercial (CC BY-NC 4.0) license, which permits others to distribute, remix, adapt, build upon this work non-commercially, 
and license their derivative works on different terms, provided the original work is properly cited, appropriate credit is given, any changes made indicated, and the use is non-commercial. See: http://creativecommons.org/licenses/by-nc/4.0/.

\section{ORCID iD}

Jorge A Huete-Pérez http://orcid.org/0000-0001-5259-8428

\section{REFERENCES}

1 World Health Organization. WHO coronavirus disease (COVID-19) dashboard [online]. Geneva, 2020. https://covid19.who.int/

2 Díaz López K. Vacunas contra el Covid-19 en Nicaragua: Cuántas tiene aseguradas el país para los próximos días [ Vaccines against Covid-19 in Nicaragua: how many has the country secured for the next few days]. La Prensa [online], 2021. Available: https://www. laprensa.com.ni/2021/02/28/nacionales/2790405-vacunas-contra-elcovid-19-en-nicaragua-cuantas-tiene-aseguradas-el-pais-para-losproximos-dias

3 Citizen Observatory. Observatorio Ciudadano COVID-19 en Nicaragua. Informe Semanal 11/02/2021 al 17/02/2021 [Citizen Observatory COVID-19 weekly report in Nicaragua 02/11/2021 to 02/17/2021 [online]. Available: https://observatorioni.org/informesnotas-y-semanales/ [Accessed 25 Nov 2020].

4 Romero KT. Fatality in the country soared in 2020 due to the pandemic. Confidencial 2021 https://confidencial.com.ni/nacion/ mortalidad-en-nicaragua-aumento-en-2020-COVID-19/

5 Hotez PJ, Huete-Perez JA, Bottazzi ME. COVID-19 in the Americas and the erosion of human rights for the poor. PLoS Negl Trop Dis 2020;14:p. e0008954.

6 COVID-19 Impact on Education [online]. Paris: UNESCO, 2020. Available: https://en.unesco.org/themes/education-emergencies/ coronavirus-school-closures [Accessed 4 Mar 2021].

7 Mehta NS, Mytton OT, Mullins EWS, et al. SARS-CoV-2 (COVID-19): what do we know about children? A systematic review. Clin Infect Dis 2020;71:1:2469-79. doi:10.1093/cid/ciaa556

8 Kim L, Whitaker M, O'Halloran A, et al. Hospitalization rates and characteristics of children aged $<18$ years hospitalized with laboratory-confirmed COVID-19 - COVID-NET, 14 States, March 1July 25, 2020. MMWR Morb Mortal Wkly Rep 2020;69:1081-8.

$9 \mathrm{Bi} \mathrm{Q}$, Wu Y, Mei S. Epidemiology and transmission of COVID-19 in 391 cases and 1286 of their close contacts in Shenzhen, China: a retrospective cohort study. Lancet Infect Dis 2020;20:911-9.

10 Zimmermann P, Curtis N. Coronavirus infections in children including COVID-19: an overview of the epidemiology, clinical features, diagnosis, treatment and prevention options in children. Pediatr Infect Dis J 2020;39:355-68.

$11 \mathrm{Li} \mathrm{X,} \mathrm{Xu} \mathrm{W,} \mathrm{Dozier} \mathrm{M.} \mathrm{The} \mathrm{role} \mathrm{of} \mathrm{children} \mathrm{in} \mathrm{transmission} \mathrm{of} \mathrm{SARS-}$ CoV-2: a rapid review. J Glob Health 2020;10:11101.

12 Huete-Pérez JA, Cabezas-Robelo C, Páiz-Medina L, et al. First report on prevalence of SARS-CoV-2 infection among health-care workers in Nicaragua. PLoS One 2021;16 doi:10.1371/journal.pone.0246084

13 Rodino KG, Espy MJ, Buckwalter SP, et al. Evaluation of saline, phosphate-buffered saline, and minimum essential medium as potential alternatives to viral transport media for SARS-CoV-2 testing. J Clin Microbiol 2020;58 doi:10.1128/JCM.00590-20

14 Zhang Y, Odiwuor N, Xiong J. Rapid molecular detection of SARSCoV-2 (COVID-19) virus RNA using colorimetric lamp. medRxiv 2020 http://medrxiv.org/content/early/2020/02/29/2020.02.26.20028373. abstract

15 Zhang Y, Ren G, Buss J, et al. Enhancing colorimetric loop-mediated isothermal amplification speed and sensitivity with guanidine chloride. Biotechniques 2020;69:178-85. doi:10.2144/btn-2020-0078

16 National Institute of Health. COVID-19 treatment guidelines panel: clinical spectrum of SARS-CoV-2 infection [Internet]. Bethesda, MD: National Institutes of Health, 2020. https://www.covid19treatment guidelines.nih.gov/overview/clinical-spectrum/

17 Laxminarayan R, Wahl B, Dudala SR, et al. Epidemiology and transmission dynamics of COVID-19 in two Indian states. Science 2020;370:691-7. doi:10.1126/science.abd7672

18 Louca S. COVID-19 prevalence in 161 countries and over time. medRxiv [online] 2020 http://medrxiv.org/content/early/2020/12/02/ 2020.12.01.20241539.abstract

19 Dong Y, Mo X, Hu Y, et al. Epidemiology of COVID-19 among children in China. Pediatrics 2020;145 doi:10.1542/peds.2020-0702

20 Götzinger F, Santiago-García B, Noguera-Julián A, et al. COVID-19 in children and adolescents in Europe: a multinational, multicentre cohort study. Lancet Child Adolesc Health 2020;4:653-61. doi:10.1016/S2352-4642(20)30177-2

21 Alsohime F, Temsah M-H, Al-Nemri AM, et al. COVID-19 infection prevalence in pediatric population: etiology, clinical presentation, and outcome. J Infect Public Health 2020;13:1791-6. doi:10.1016/j. jiph.2020.10.008

22 Madewell ZJ, Yang Y, Longini IM, et al. Household transmission of SARS-CoV-2: a systematic review and meta-analysis. JAMA Netw Open 2020;3:e2031756. doi:10.1001/jamanetworkopen.2020.31756

23 Chua GT, Wong JSC, Lam I, et al. Clinical characteristics and transmission of COVID-19 in children and youths during 3 waves of outbreaks in Hong Kong. JAMA Netw Open 2021;4:e218824. doi:10.1001/jamanetworkopen.2021.8824

24 Hoang A, Chorath K, Moreira A, et al. COVID-19 in 7780 pediatric patients: a systematic review. EClinicalMedicine 2020;24:100433. doi:10.1016/j.eclinm.2020.100433

25 Waterfield T, Watson C, Moore R. Seroprevalence of SARS-CoV-2 antibodies in children: a prospective multicentre cohort study. Arch Dis Child 2020

26 Rubens JH, Akindele NP, Tschudy MM, et al. Acute COVID-19 and multisystem inflammatory syndrome in children. BMJ 2021;372:n385. doi:10.1136/bmj.n385

27 Xiong X, Wong KK, Chi S. Comparative study of the clinical characteristics and epidemiological trend of 244 COVID-19 infected children with or without Gi symptoms. Gut 2021;70:438.

28 Ludvigsson JF. Systematic review of COVID-19 in children shows milder cases and a better prognosis than adults. Acta Paediatr 2020;109:1088-95. doi:10.1111/apa.15270

29 Liguoro I, Pilotto C, Bonanni M, et al. SARS-COV-2 infection in children and newborns: a systematic review. Eur $J$ Pediatr 2020;179:1029-46. doi:10.1007/s00431-020-03684-7

30 Chua GT, Xiong X, Choi EH. COVID-19 in children across three Asian cosmopolitan regions. Emerg Microbes \\& Infect 2020;9:2588-96.

31 Jones NR, Qureshi ZU, Temple RJ, et al. Two metres or one: what is the evidence for physical distancing in COVID-19? BMJ 2020;370:m3223. doi:10.1136/bmj.m3223

32 Ganguli A, Mostafa A, Berger J, et al. Rapid isothermal amplification and portable detection system for SARS-CoV-2. Proc Natl Acad Sci U S A 2020;117:22727-35. doi:10.1073/pnas.2014739117

33 Food and Drug Administration (US). Emergency Use Autorization (EUA) summary for the color SARS-COV-2 RT-LAMP diagnostic assay. Silver Spring, MD: Food and Drug Administration (US, 2020.

34 Augustine R, Hasan A, Das S, et al. Loop-mediated isothermal amplification (lamp): a rapid, sensitive, specific, and cost-effective point-of-care test for coronaviruses in the context of COVID-19 pandemic. Biology 2020;9 doi:10.3390/biology9080182

35 Lalli MA, Langmade JS, Chen X. Rapid and extraction-free detection of SARS-CoV-2 from saliva by colorimetric reverse-transcription loop-mediated isothermal amplification. Clin Chem 2021;67:415-24.

36 El-Tholoth $\mathrm{M}$, Bau HH, Song J. A single and two-stage, closedtube, molecular test for the 2019 novel coronavirus (COVID-19) at home, clinic, and points of entry. ChemRxiv 2020 doi:10.26434/ chemrxiv.11860137

37 Yang Q, Meyerson NR, Clark SK. Saliva twostep: an RT-LAMP saliva test for SARS-CoV-2 and its assessment in a large population. medRxiv 2020.

38 Dao Thi VL, Herbst K, Boerner K, et al. A colorimetric RT-LAMP assay and LAMP-sequencing for detecting SARS-CoV-2 RNA in clinical samples. Sci Transl Med 2020;12:1. doi:10.1126/ scitransImed.abc7075

39 Yan C, Cui J, Huang L, et al. Rapid and visual detection of 2019 novel coronavirus (SARS-CoV-2) by a reverse transcription loopmediated isothermal amplification assay. Clin Microbiol Infect 2020;26:773-9. doi:10.1016/j.cmi.2020.04.001

40 Aoki MN, de Oliveira Coelho B, Góes LGB, et al. Colorimetric RT-LAMP SARS-CoV-2 diagnostic sensitivity relies on color interpretation and viral load. Sci Rep 2021;11:9026. doi:10.1038/ s41598-021-88506-y

41 Chua GT, Wong JSC, KKW T. Saliva viral load better correlates with clinical and immunological profiles in children with coronavirus disease 2019. Emerg Microbes \& Infect 2021;10:235-41.

42 Shadmi E, Chen Y, Dourado I, et al. Health equity and COVID-19: global perspectives. Int J Equity Health 2020;19. doi:10.1186/ s12939-020-01218-z

43 Huete-Pérez J, Hildebrand J. Nicaragua's COVID-19 crisis demands a response. Sills J, editor. Science 2020;369.

44 Salazar Mather TP, Gallo Marin B, Medina Perez G, et al. Love in the time of COVID-19: negligence in the Nicaraguan response. Lancet Glob Health 2020;8:e773. doi:10.1016/S2214-109X(20)30131-5 